\title{
ANALISIS PENGARUH FAKTOR INTERNAL DAN EKSTERNAL TERHADAP HARGA SAHAM \\ (Studi Kasus pada Perusahaan Sektor Property dan Real Estate yang Terdaftar di BEI)
}

\author{
Bella Anindita Apsari \\ David Kaluge \\ Fakultas Ekonomi dan Bisnis Universitas Brawijaya Malang \\ Jalan MT. Haryono No.165, Jawa Timur 65145, Indonesia \\ Email: bell_abel@ymail.com
}

\begin{abstract}
The existence of capital market in Indonesia can be seen from the number of investors who invest their shares in property and real estate sectors. From the perspective of the macro economy, the property sector has a very broad scope of business so that the stimulation of business property in turn will affect the economic growth and work opportunities. Property also be an important indicator of economic health of a country. In this research, are considered internal factors that affect stock prices and the real estate property sector is to look at financial ratios such as the ratio of Return On Equity (ROE) dan Earning Per Share (EPS) while external factors were used in this study is variable exchange rate and BI Rate This study uses 8 company property and real estate sector with the best issuer ratings, with a study period of years 2010-2014 (annual period). The technique analysis panel regression. The results of this research is the Return On Equity (ROE) have a a significant negative effect on stock prices and the real estate property sector, Earning Per Share (EPS) have a a significant positive effect on stock prices and the real estate property sector, exchange rate have a not significant positive effect on stock prices and the real estate property sector, BI Rate have a a not significant negative effect on stock prices and the real estate property sector.
\end{abstract}

Key words: Stock Price Property and Real Estate Sector, ROE, EPS, exchange rate and BI Rate 


\section{PENDAHULUAN}

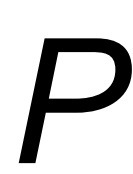

asar modal mempunyai peranan yang sangat penting di dalam kegiatan perekonomian sehingga dipandang sebagai salah satu barometer kondisi perekonomian suatu negara. Pasar modal merupakan pasar yang memperjualbelikan modal jangka panjang dalam bentuk surat berharga seperti obligasi dan saham (Kasmir, 2010:51).Kehadiran pasar modal di Indonesia ditandai dengan banyaknya investor yang mulai menanamkan sahamnya dalam industri real estate and property. Semakin pesatnya perkembangan sektor property ini diikuti dengan semakin tingginya permintaan akan kebutuhan papan, sehingga membuat para investor property membutuhkan dana dari sumber eksternal. Dana dari sumber eksternal dapat diperoleh melalui pasar modal (Husnan,1998).

Dalam berinvestasi, para investor memerlukan beberapa informasi keuangan untuk mencapai hasil yang mereka inginkan. Salah satu informasi tersebut yaitu informasi mengenai kinerja perusahaan yang dapat dilihat dari laporan keuangan. Laporan keuangan merupakan akhir dari suatu proses akuntansi yang bertujuan untuk memberikan informasi keuangan mengenai kondisi perusahaan dalam suatu periode (Harahap, 2004:105).Laporan keuangan memberikan beberapa informasi keuangan yang dibutuhkan oleh para investor maupun kreditor. Melalui analisis keuangan yang cermat dari laporan keuangan suatu perusahaan akan mampu menyoroti kekuatan serta kelemahan perusahaan tersebut. Tujuan para investor atau pemegang saham berinvestasi pastinya yaitu untuk mendapatkan keuntungan, selain dividen investor juga mengharapkan return saham.

Obyek yang digunakan dalam penelitian ini adalah sektor property dan real estateyang terdaftar di Bursa Efek Indonesia. Hal ini ditandai dengan maraknya pembangunan perumahan, apartemen, perkantoran dan perhotelan. Disamping itu, perkembangan sektor property juga dapat dilihat dari menjamurnya real estate di kota-kota besar.Dari perspektif makro ekonomi, sektor property memiliki cakupan usaha yang amat luas sehingga bergairahnya bisnis property pada gilirannya akan berpengaruh terhadap pertumbuhan ekonomi dan terbukanya lapangan kerja.Pada penelitian ini faktor internal yang dianggap berpengaruh terhadap harga saham sektor property dan real estate adalah dengan melihat rasio-rasio 
keuangan seperti rasio Return On Equity (ROE) dan Earning Per Share (EPS) sedangkan faktor eksternal yang digunakan dalam penelitian ini adalah variabel kurs dan BI Rate.Melihat fenomena harga saham pada sektor property dan real estate selama periode 2010 - 2014, penelitian ini bertujuan untuk menganalisis pengaruh return on equity (ROE), EPS (Earning Per Share), Kurs dan BI Rate terhadap harga saham sektor property dan real estateselama periode 2010 - 2014.

\section{Investor Dalam Melihat Pergerakan Harga Saham}

Saham dapat didefinisikan sebagai tanda penyertaan atau pemilikan seseorang atau badan terhadap suatu perusahaan atau perseroan terbatas. Wujud saham adalah selembar kertas yang menerangkan bahwa pemilik kertas adalah pemilik perusahaan yang menerbitkan surat tersebut. Kertonegoro (1995:99) mendefinisikan saham sebagai bentuk modal penyertaan (equity capital) atau bukti posisi kepemilikan dalam suatu perusahaan.Menurut Robbert Ang (1997), saham adalah surat berharga sebagai bukti penyertaan atau pemilikan individu maupun institusi dalam suatu perusahaan.

Return saham merupakan salah satu faktor yang memotivasi investor berinvestasi dan juga merupakan imbalan atas keberanian investor menanggung risiko atas investasi yang dilakukannya. Pembahasan tentang tingkat keuntungan sekuritas dapat dikelompokan dalam dua teori yaitu Capital Asset Pricing Model (CAPM) dan Arbitrage Pricing Theory (APT) (Suad Husnan, 2005).

Capital Asset Pricing Model (CAPM) menggambarkan hubungan tingkat return dan risiko secara sederhana dan hanya menggunakan satu variabel (variabel beta) untuk menggambarkan risiko. Sedangkan Arbitrage Pricing Theory (APT) menggunakan sekian banyak variabel pengukur risiko untuk melihat hubungan return dan risiko atau dengan kata lain APT tidak menjelaskan faktor-faktor apa yang mempengaruhi pricing (Tandelilin, 2001).APT (Arbitrage Pricing Theory) pada dasarnya menggunakan pemikiran yang menyatakan bahwa dua kesempatan investasi yang mempunyai karakteristik yang sama tidaklah bisa dijual dengan harga yang berbeda. Konsep yang dipergunakan adalah hukum satu harga (the law of the one price). Apabila aktiva yang berkarakteristik sama tersebut

QE Journal | Vol.04 - No.04 December 2015 - 217 
dengan harga yang berbeda, maka akan terdapat kesempatan untuk melakukan arbitrage dengan membeli aktiva yang berharga murah dan pada saat yang sama menjualnya dengan harga yang lebih tinggi sehingga memperoleh laba tanpa risiko (Husnan, 2003).

Sedangkan Copeland (1997) menyatakan bahwa paling sedikit ada 3 atau 4 faktor yang mempengaruhi perkembangan harga dari surat-surat berharga. Hal ini menunjukkan bahwa teori APT mendorong adanya pengembangan penelitian berdasarkan variabel atau faktor-faktor yang diduga mempengaruhi perubahan sebuah sekuritas. Faktor-faktor itu dapat dilihat dari kinerja fundamental perusahaan, kinerja saham di pasar, ataupun keadaan pasar dan perekonomian.

\section{Rasio Keuangan}

Rasio adalah alat yang dapat digunakan untuk menjelaskan hubungan antara dua macam data finansial. Rasio menggambarkan suatu hubungan atau perimbangan (mathematical relationship) antara suatu jumlah tertentu dengan jumlah yang lain (Munawir, 2000:54). Rasio sebenarnya hanyalah alat yang dinyatakan dalam aritmathical terms yang dapat digunakan untuk menjelaskan hubungan antara dua macam data finansial (Bambang Riyanto, 2001:329). Rasio keuangan merupakan suatu informasi yang menggambarkan hubungan antara berbagai macam akun (accounts) dari laporan keuangan yang mencerminkan keadaan keuangan serta hasil operasional perusahaan.

Menurut Robert Ang (1997) rasio keuangan dapat dikelompokkan m enjadi lima jenis berdasarkan ruang lingkup atau tujuan yang ingin dicapai, yaitu:

1) Rasio Likuiditas (Liquidity Ratios)

Rasio ini menyatakan kemampuan perusahaan jangka pendek untuk memenuhi obligasi (kewajiban) yang jatuh tempo. Rasio likuiditas ini $t$ erdiri dari: current ratio (rasio lancar), quick ratio, dan net working capital.

2) Rasio Aktivitas (Activity Ratios)

Rasio ini menunjukkan kemampuan serta efisiensi perusahaan didalam memanfaatkan harta-harta yang dimilikinya. Rasio aktivitas ini terdiri dari : total asset turnover, fixed asset turnover, accounts receivable turnover, inventory turnover, average collection period (day's sales inaccounts receivable) dan day's sales in inventory. 
3) Rasio Rentabilitas/Profitabilitas (Profitability Ratios)

Rasio ini menunjukkan keberhasilan perusahaan didalam menghasilkan keuntungan. Rasio rentabilitas ini terdiri dari: gross profit margin, net profit margin, operating return on assets, return on assets, return on equity, dan operating ratio.

4) Rasio Solvabilitas (Solvency Ratios)

Rasio ini menunjukkan kemampuan perusahaan untuk memenuhi kewajiban jangka panjangnya. Rasio ini juga disebut leverage ratios, karena merupakan rasio pengungkit yaitu menggunakan uang pinjaman (debt) untuk memperoleh keuntungan. Ras io leverage ini terdiri dari: debt ratio, debt to equity ratio, long -term debt to equity ratio, long-term debt to capitalization ratio, times interest earned, cash flow interest coverage, cash flow to net income, dan cash return on sales.

5) Rasio Pasar (Market Ratios)

Rasio ini menunjukkan informasi penting perusahaan yang diungkapkan dalam basis per saham. Rasio pasar ini terdiri dari: dividend yield, dividend per share, earning per share, dividend payout ratio, price earning ratio, book value per share, dan price to book value.

\section{Return On Equity (ROE)}

Rasio profitabilitas merupakan rasio yang digunakan untuk menilai kemampuan suatu perusahaan di dalam mencari keuntungan. Rasio ini juga mencerminkan tingkat efektivitas manajemen perusahaan yang dapat dilihat dari laba yang dihasilkan melalui penjualan dan pendapatan investasi (Kasmir, 2010:115). Dalam penelitian ini menggunakan return on equity (ROE) sebagai rasio profitabilitas karena dengan mengetahui besarnya ROE, maka investor akan dapat menilai prospek suatu perusahaan tersebut kedepannya serta para investor dapat melihat sejauh mana pertumbuhan profitabilitas perusahaan tersebut.Indikator ROE mampu mencerminkan sejauh mana investasi yang akan dilakukan oleh investor di suatu perusahaan tersebut dapat memberikan return yang sesuai dengan yang diharapkan oleh investor (Hasanah, 2008). Semakin tinggi ROE mencerminkan kemampuan perusahaan dalam menghasilkan keuntungan bagi pemegang saham juga tinggi. Dalam penelitian Hasanah (2008) membuktikan bahwa ROE berpengaruh negatif dan signifikan terhadap return saham. Sedangkan penelitian yang dilakukan oleh 
Sasongko (2006) menunjukkan bahwa ROE tidak berpengaruh terhadap return saham.

\section{Earning Per Share ( EPS )}

Earning per share (Laba perlembar saham) merupakan indikator yang secara ringkasmenyajikan kinerja perusahaan yang dinyatakan dengan laba. Menurut Tjiptono Darmadji dan Hendy M (2001) pengertian laba per lembar saham atau EPS merupakan rasio yang menunjukkan berapa besar keuntungan (laba) yang diperoleh investor atau pemegang saham per lembar sahamnyaIndikator EPS (Earning Per Share) Menurut Fahmi Irham (2012:96) EPS atau pendapatan perlembar saham adalah bentuk pemberian keuntungan yang diberikan kepada pemegang saham dari setiap lembar saham yang dimiliki. Dengan menggunakan analisis EPS maka dapat diketahui seberapa besar kemajuan yang telah dicapai perusahaan dalam menghasilkan keuntungan per lembar saham. Menurut Setyawan (2014), menunjukkan hasil bahwa ROE, dan EPS mempunyai pengaruh signifikan terhadap harga saham.

Rasio EPS yang terus meningkat menggambarkan bahwa perusahaan mempunyai kinerja yang baik, sehingga membuat para investor tertarik untuk membeli saham perusahaan. Dengan meningkatnya rasio EPS dan semakin meningkatnya permintaan saham perusahaan akan mengakibatkan naiknya harga saham perusahaan tersebut. Investor sangat menyukai EPS perusahaan yang tinggi dikarena EPS merupakan bentuk keuntungan nyata yang akan diterima oleh investor. Semakin tinggi EPS perusahaan maka semakin tinggi juga keuntungan yang akan diterima oleh investor.

\section{Kurs}

Fluktuasi nilai tukar suatu mata uang juga dapat mempengaruhi kegiatan dan nilai pasar atas pasar lokal, jika perusahaan pada taraf persaingan internasional, hal ini berarti return saham perusahaan dipengaruhi oleh perubahan nilai tukar mata uang karena berdampak terhadap laporan perdagangan dan modal atas keseimbangan pembelian dalam negeri. Suseno (1990) menyatakan bahwa nilai tukar rupiah yang relatif rendah 
terhadap mata uang negara lain terutama US\$ akan mendorong peningkatan ekspor dan dapat mengurangi laju pertumbuhan impor. Nilai tukar rupiah yang rendah juga akan mendorong melemahnya daya beli masyarakat yang dapat memicu kurang menariknya tingkat investasi dalam rupiah.

Nilai tukar merupakan perbandingan nilai atau harga dua mata uang. Pengertian nilai tukar mata uang menurut FASB adalah rasio antara suatu unit mata uang dengan sejumlah mata uang lain yang bisa ditukar pada waktu tertentu. Perbedaan nilai tukar riil dengan nilai tukar nominal penting untuk dipahami karena keduanya mempunyai pengaruh yang berbeda terhadap risiko nilai tukar (Sartono, 2001). Kurs merupakan variabel makroekonomi yang turut mempengaruhi volatilitas harga saham. Depresiasi mata uang domestik akan meningkatkan volume ekspor. Bila permintaan pasar internasional cukup elastis hal ini akan meningkatkan cash flow perusahaan domestik, yang kemudian meningkatkan harga saham, yang tercermin pada IHSG. Sebaliknya, jika emiten membeli produk dalam negeri, dan memiliki hutang dalam bentuk dollar maka harga sahamnya akan turun. Depresiasi kurs akan menaikkanharga saham. Penelitian yang dilakukan oleh Hardiningsih et al. (2001) menunjukkan hasil bahwa nilai tukar rupiah terhadap US Dollar berpengaruh negative terhadap return saham. Disisi lain, Utami dan Rahayu (2003) serta Suciwati dan Machfoedz (2002) hasilnya menunjukkan bahwa nilai tukar rupiah terhadap US Dollar berpengaruh positif terhadap return saham.

\section{BI Rate}

Tingkat suku bunga menyatakan tingkat pembayaran atas pinjaman atau investasi lain, di atas perjanjian pembayaran kembali, yang dinyatakan dalam persentase tahunan (Dornbusch, et.al., 2008:43).Menurut PBI No. 4/10/PBI/2002 tentang Sertifikat Bank Indonesia, SBI adalah surat berharga dalam mata uang Rupiah yang diterbitkan oleh Bank Indonesia sebagai pengakuan utang berjangka waktu pendek. Tingkat suku bunga ini ditentukan oleh mekanisme pasar berdasarkan sistem lelang.

Tingkat bunga yang tinggi merupakan sinyal negatif terhadap harga saham. Tingkat suku bunga yang meningkat akan meningkatkan suku bunga yang diisyaratkan atas investasi pada suatu saham. Di samping itu,

QE Journal | Vol.04 - No.04 December 2015 - 221 
tingkat suku bunga yang meningkat bias juga menyebabkan investor menarik investasinya pada saham dan memindahkannya pada investasi berupa tabungan ataupun deposito.Weston dan Brigham (1994) mengemukakan bahwa tingkat bunga mempunyai pengaruh yang besar terhadap harga saham. Suku bunga yang makin tinggi memperlesu perekonomian, menaikan biaya bunga dengan demikian menurunkan laba perusahaan, dan menyebabkan para investor menjual saham dan mentransfer dana ke pasar obligasi. Kestabilan nilai tukar rupiah terhadap mata uang asing juga mempengaruhi,'BI rate yang tinggi akan mengundang arus masuk dana asing alias hot money dengan deras. Situasi ini akan memperkuat nilai tukar rupiah. Begitu juga sebaliknya. Selisih (spread) antara BI rate dengan bunga acuan di Amerika Serikat, Fed funds rate.Semakin besar selisih kedua bunga ini, semakin menarik Indonesia di mata investor global. Jadi, jika AS menaikkan bunga sementara BI rate tetap, maka indonesia tidak akan menjadi jujukan untuk investasi.(Yuliana, 2010)

\section{METODE PENELITIAN}

Berdasarkan dengan tujuannya, penelitian ini menggunakan pendekatan deskripsi kuantitatif. Jenisdatayang digunakan dalam penelitian ini adalah data sekunder yaitu data yang diperoleh dari pihak lain dalam bentuk data yang sudah jadi atau berupa publikasi. Sumber data dalam penelitian ini diperoleh dari laporan historis rasio-rasio keuangan masing-masing perusahaan, data yang digunakan diperoleh dari idx dan www.bi.go.id dan www.yahoofinance.com, perusahaan yang tercatat di Bursa Efek Indonesia (BEI) serta laporan keuangan tahunan perusahaan sektor property dan real estate periode 2010 - 2014 yang tersedia dan dipublikasikan di website resmi Indonesia Stock Exchange (IDX). Adapun jumlah observasi yang digunakan adalah berjumlah 8 perusahaan sektor property dan real estate dengan peringkat emiten terbaik dan telah go public di Indonesia pada periode tahun 2010-2014.Dalam penelitian ini, populasi yang digunakan adalah seluruh perusahaan pada sektor property dan real estate yang telah go public di Indonesia pada periode tahun 2010 2014 dan terdaftar di Bursa Efek Indonesia.Sampel pada penelitian ini diambil dengan menggunakan metode purposive sampling, yaitu dengan kriteria perusahaan pada sektor property dan real estate yang menempati 
peringkat emiten terbaik dan tersedia laporan keuangan pada kurun waktu tahun 2010 - 2014.

Dalam penelitian ini metode analisis data yang digunakan adalah model regresi data panel dengan menggunakan software Eviews-7 untukmengujipengaruhDana Pihak Ketiga (DPK), Capital Adequacy Ratio (CAR), Non Performing Loan (NPL), Return on Asset (ROA) dan suku bunga Sertifikat Bank Indonesia (SBI) terhadapvariabeldependenyaitutotal kredit.Data panel adalah gabungan antara data runtut waktu (time series) dan data silang (cross section).

Dengan pengamatan berulang terhadap data cross section yang cukup, analisis data panel memungkinkan seseorang dalam mempelajari dinamika perubahan dengan dengan data time series. Kombinasi data time series dan cross section dapat meningkatkan kualitas dan kuantitas data dengan pendekatan yang tidak mungkin dilakukan dengan menggunakan hanya salah satu dari data tersebut (Gujarati, 1999).

Maka dapat dituliskan model sebagai berikut :

$$
\begin{gathered}
Y_{i t}=\propto+\beta_{1} X_{i t}+\beta_{2} X_{i t}+\beta_{3} X_{i t}+\beta_{4} X_{i t}+\varepsilon_{i t}, \\
i=1,2, \ldots \ldots \ldots N ; t=1,2, \ldots \ldots \ldots T
\end{gathered}
$$

Dimana:

Y: Variabel Dependen

(Harga Saham)

$\alpha$ : Konstanta

$X$ : Variabel Independen

ROE, EPS, KURS dan BI Rate

$\beta(1 \ldots 4)$ : koefesien regresi masing-masing variabel independen

$n$ : Banyaknya observasi

( 8 perusahaan sektor property dan real estate dengan emiten terbaik)

$t$ : Banyaknya waktu (2020-2014)

$n x t \quad$ :Banyaknya data panel 


\section{Common Effect Model /Pooled Least Square (PLS)}

Merupakan pendekatan model data panel yang paling sederhana karena hanya mengkombinasikan data time series dan cross section. Pada model ini tidak diperhatikan dimensi waktu maupun individu, sehingga diasumsikan bahwa perilaku data perusahaan sama dalam berbagai kurun waktu. Metode ini bisa menggunakan pendekatan Ordinary Least Square (OLS).

\section{Fixed Effect Model}

Model ini mengasumsikan bahwa perbedaan antar individu dapat diakomodasi dari perbedaan intersepnya. Untuk mengestimasi data panel model Fixed Effects menggunakan teknik variable dummy untuk menangkap perbedaan intersep antar data. Model estimasi ini sering juga disebut dengan teknik Least Squares Dummy Variable (LSDV). Metode fixed effect dapat mengatasi hal tersebut karena metode ini memunkinkan adanya perubahan pada setiap i dan $\mathrm{t}$.

\section{Random Effect Model}

Model ini akan mengestimasi data panel dimana variabel gangguan mungkin saling berhubungan antar waktu dan antar individu. Pada model Random Effect perbedaan intersep diakomodasi oleh error terms masingmasing. Keuntungan menggunkan model Random Effect yakni menghilangkan heteroskedastisitas. Model ini juga disebut dengan Error Component Model (ECM) atau teknik Generalized Least Square (GLS). Dapat dinyatakan bahwa model random effect menganggap efek rata-rata dari data cross section dan time series direpresentasikan dalam intercept.

\section{Pemilihan Spesifikasi Model Terbaik}

Terdapat tiga macam pendekatan dalam metode analisa yang bisa digunakan dalam analisis regresi data panel, yaitu model Common Effect, model efek tetap (Fixed Effect), dan model efek acak (Random Effect). Untuk memilih salah satu model estimasi yang dianggap paling tepat dari tiga jenis model data panel, maka perlu dilakukan serangkaian uji, yaitu:

1. Uji Chow statistik digunakan untuk menentukan metode antara pendekatan common effect dan fixed effect. 
2. Uji Hausman digunakan untuk menentukan metode antara pendekatan random effect dan fixed effect.

\section{HASIL DAN PEMBAHASAN}

\section{Perkembangan Harga Saham}

Berikut ini tabel pergerakan harga saham pada sector property dan real estate pada 8 perusahaan dengan emiten terbaik yang terdaftar di BEI periode penelitian 2010 - 2014.

Tabel 4.1. Perkembangan Harga Saham Sektor Property dan Real Estate

\begin{tabular}{|c|c|c|c|c|c|c|c|c|}
\hline \multirow{2}{*}{$\begin{array}{l}\text { KODE } \\
\text { PERUSAHAAN }\end{array}$} & \multicolumn{5}{|c|}{ Tahun } & \multirow{2}{*}{ MIN } & \multirow{2}{*}{ MAX } & \multirow{2}{*}{ MEAN } \\
\hline & 2010 & 2011 & 2012 & 2013 & 2014 & & & \\
\hline APLN & 385 & 350 & 365 & 215 & 335 & 215 & 385 & 330 \\
\hline ASRI & 295 & 460 & 600 & 430 & 560 & 295 & 600 & 469 \\
\hline BSDE & 900 & 980 & 1100 & 1290 & 1805 & 900 & 1805 & 1215 \\
\hline CTRA & 350 & 540 & 790 & 750 & 1250 & 350 & 1250 & 736 \\
\hline CTRP & 690 & 870 & 2200 & 3820 & 2960 & 690 & 3820 & 2108 \\
\hline LPCK & 395 & 1790 & 3200 & 4875 & $\begin{array}{l}1040 \\
0\end{array}$ & 395 & 10400 & 4132 \\
\hline LPKR & 680 & 660 & 1000 & 910 & 1020 & 660 & 1020 & 854 \\
\hline PWON & $\begin{array}{l}867,4 \\
7\end{array}$ & 750 & 215 & 270 & 515 & 215 & 867,5 & 523,5 \\
\hline
\end{tabular}

Berdasarkan tabel diatas, rata-rata pergerakan harga saham pada sektor property dan real estate tertinggi selama 5 tahun terakir pada 8 perusahaan dengan emiten terbaik terjadi pada perusahaan Lippo Cikarang, Tbk. Nilai 4132 mengintrepetasikan bahwa perusahaan tersebut menunjukkan kemampuannya dalam mengelola harga saham sebesar 4132 (dalam jutaan ruapiah). Hal ini dapat dikatakan bahwa perusahaan Lippo Cikarang, Tbk mampu menarik minat investor untuk berinvestasi pada perusahaan tersebut. Sedangkan rata-rata pergerakan harga saham pada sektor property dan real estate terendah terjadi pada perusahaan Agung Podomoro Land, Tbk. Nilai 330 mengintrepetasikan bahwa perusahaan Agung Podomoro Land, Tbk menunjukkan kemampuannya yang rendah dalam hal menarik minat investor dalam berinvestasi pada perusahaannya dengan jumlah saham yang terhimpun cukup rendah yaitu sebesar 330 ( 
dalam jutaan rupiah) pada 5 tahun terakir. Dalam hal ini perusahaan Agung Podomoro Land, Tbk belum menjalankan kinerjanya dengan bagus.

\section{Perkembangan ROE (Return on Equity)}

Rasio profitabilitas merupakan rasio yang digunakan untuk menilai kemampuan suatu perusahaan di dalam mencari keuntungan. Rasio ini juga mencerminkan tingkat efektivitas manajemen perusahaan yang dapat dilihat dari laba yang dihasilkan melalui penjualan dan pendapatan investasi (Kasmir, 2010:115). Peneliti menggunakan return on equity (ROE) sebagai rasio profitabilitas karena dengan mengetahui besarnya ROE, maka investor akan dapat menilai prospek suatu perusahaan tersebut kedepannya serta para investor dapat melihat sejauh mana pertumbuhan profitabilitas perusahaan tersebut. Indikator ROE mampu mencerminkan sejauh mana investasi yang akan dilakukan oleh investor di suatu perusahaan tersebut dapat memberikan return yang sesuai dengan yang diharapkan oleh investor (Hasanah, 2008). Semakin tinggi ROE mencerminkan kemampuan perusahaan dalam menghasilkan keuntungan bagi pemegang saham juga tinggi. harga saham perusahaan tersebut.

Pada penelitian ini rasio ROE merupakan rasio yang mempunyai pengaruh dominan terhadap harga saham. Berikut tabel nilai ROE pada perusahaan sector property dan real estate yang terdaftar di BEI periode penelitian 2010 - 2014.

Tabel 4.2. Perkembangan ROE pada Perusahaan Sektor Property dan Real Estate

\begin{tabular}{|c|c|c|c|c|c|c|c|c|}
\hline \multirow{2}{*}{$\begin{array}{l}\text { KODE } \\
\text { perusahaan }\end{array}$} & \multicolumn{5}{|c|}{ Tahun } & \multirow{2}{*}{$\begin{array}{l}\text { MI } \\
\mathrm{N}\end{array}$} & \multirow{2}{*}{$\begin{array}{l}\text { MA } \\
X\end{array}$} & \multirow{2}{*}{$\begin{array}{l}\text { MEA } \\
\mathrm{N}\end{array}$} \\
\hline & 2010 & 2011 & 2012 & 2013 & 2014 & & & \\
\hline APLN & 10 & 14,8 & 12,6 & 13,7 & 14,8 & 10 & 14,8 & 13,18 \\
\hline ASRI & 13 & 22 & 26 & 17 & 18 & 13 & 26 & 19,2 \\
\hline BSDE & 11,6 & 12,2 & 16,25 & 26,32 & 24,84 & 12 & 26,32 & 18,24 \\
\hline CTRA & 5,3 & 6,4 & 10,5 & 15,3 & 17,9 & 5,3 & 17,9 & 11,08 \\
\hline CTRP & 4 & 4 & 5 & 6 & 4 & 4 & 6 & 4,6 \\
\hline LPCK & 3,91 & 12,6 & 14,37 & 15,32 & 19,59 & 3,9 & 19,59 & 13,16 \\
\hline LPKR & 7 & 8 & 10 & 10 & 16 & 7 & 16 & 10,2 \\
\hline PWON & 5,5 & 6 & 9,9 & 12,2 & 15 & 5,5 & 15 & 9,72 \\
\hline
\end{tabular}


Berdasarkan tabel diatas, rata-rata ROE tertinggi pada sektor property dan real estate tertinggi selama 5 tahun terakir pada 8 perusahaan dengan emiten terbaik terjadi pada perusahaan Bumi Serpong Damai, Tbk. Nilai $18,24 \%$ mengintrepetasikan bahwa perusahaan tersebut menunjukkan kemampuannyadalam menghasilkan keuntungan bagi pemegang saham juga tinggiSedangkan rata-rata $\mathrm{ROE}$ terendah terjadi pada perusahaan Ciputra Property, Tbk. Nilai 4,6\% mengintrepetasikan bahwa perusahaan tersebut dalam menghasilkan keuntungan bagi pemegang saham juga cenderung rendah.

\section{Perkembangan EPS}

EPS merupakan rasio yang menunjukan laba bersih yang dihasilkan oleh perusahaan untuk setiap lembar saham yang diterbitkan perusahaan. Hasil analisis dari penelitian ini menunjukan bahwa EPS mempunyai pengaruh positif dan signifikan terhadap harga saham, dimana kenaikan rasio EPS akan berpengaruh pada meningkatnya harga saham. Rasio EPS yang terus meningkat menggambarkan bahwa perusahaan mempunyai kinerja yang baik, sehingga membuat para investor tertarik untuk membeli saham perusahaan. Dengan meningkatnya rasio EPS dan semakin meningkatnya permintaan saham perusahaan akan mengakibatkan naiknya harga saham perusahaan tersebut.

Berikut tabel nilai EPS pada perusahaan sector property dan real estate yang terdaftar di BEI periode penelitian 2010 - 2014.

Tabel 4.3. Perkembangan EPSpada Perusahaan Sektor Property dan Real Estate

\begin{tabular}{|c|c|c|c|c|c|c|c|c|}
\hline \multirow{2}{*}{$\begin{array}{l}\text { KODE } \\
\text { perusahaan }\end{array}$} & \multicolumn{5}{|c|}{ Tahun } & \multirow{2}{*}{ MIN } & \multirow{2}{*}{ MAX } & \multirow{2}{*}{ MEAN } \\
\hline & 2010 & 2011 & 2012 & 2013 & 2014 & & & \\
\hline APLN & 19,45 & 28,3 & 39,6 & 41,53 & $\begin{array}{l}41,7 \\
2\end{array}$ & 19 & 41,72 & 34,13 \\
\hline ASRI & 16,26 & 33,7 & 61,19 & 44,62 & $\begin{array}{l}55,8 \\
5\end{array}$ & 16 & 61,19 & 42,32 \\
\hline BSDE & 38,72 & 48,1 & 73,5 & 153,8 & $\begin{array}{l}211, \\
3\end{array}$ & 39 & 211,3 & 105,1 \\
\hline CTRA & 20,58 & 25,2 & 20,6 & 11,65 & $\begin{array}{l}14,3 \\
1\end{array}$ & 12 & 25,21 & 18,47 \\
\hline
\end{tabular}

QE Journal | Vol.04 - No.04 December 2015 - 227 


\begin{tabular}{lllllllll} 
CTRP & 25 & 26 & 49 & 71 & 66 & 25 & 71 & 47,4 \\
LPCK & 94 & 370 & 585 & 849 & 1213 & 94 & 1213 & 622,2 \\
LPKR & 30 & 32 & 46 & 34 & 112 & 30 & 112 & 50,8 \\
PWON & 6,79 & 8,62 & 15,53 & 23,52 & 51,2 & 5,8 & 51,25 & 21,14 \\
\hline
\end{tabular}

Sumber: Data diolah IDX

Menurut Fahmi Irham (2012:96) EPS atau pendapatan perlembar saham adalah bentuk pemberian keuntungan yang diberikan kepada pemegang saham dari setiap lembar saham yang dimiliki. Dengan meningkatnya rasio EPS dan semakin meningkatnya permintaan saham perusahaan akan mengakibatkan naiknya harga saham perusahaan tersebut.Berdasarkan tabel diatas, rata-rata EPS tertinggi pada sektor property dan real estate tertinggi selama 5 tahun terakir pada 8 perusahaan dengan emiten terbaik terjadi pada perusahaan Lippo Cikarang, Tbk. Nilai 622,2\% mengintrepetasikan bahwa perusahaan tersebut menunjukkan kemampuannya bahwa perusahaan mempunyai kinerja yang baik, sehingga membuat para investor tertarik untuk membeli saham perusahaan tersebut.

Sedangkan rata-rata rasio EPS terendah terjadi pada perusahaan Agung Podomoro Land, Tbk. Nilai 34,13\% mengintrepetsikan bahwa perusahaan tersebut menunjukkan kemampuannya bahwa mempunyai kinerja yang kurang baik, sehingga membuat para investor kurang tertarik untuk membeli saham perusahaan tersebut.

\section{Perkembangan Tingkat Kurs}

Nilai tukar merupakan perbandingan nilai atau harga dua mata uang. Pengertian nilai tukar mata uang menurut FASB adalah rasio antara suatu unit mata uang dengan sejumlah mata uang lain yang bisa ditukar pada waktu tertentu. Perbedaan nilai tukar riil dengan nilai tukar nominal penting untuk dipahami karena keduanya mempunyai pengaruh yang berbeda terhadap risiko nilai tukar (Sartono, 2001). 


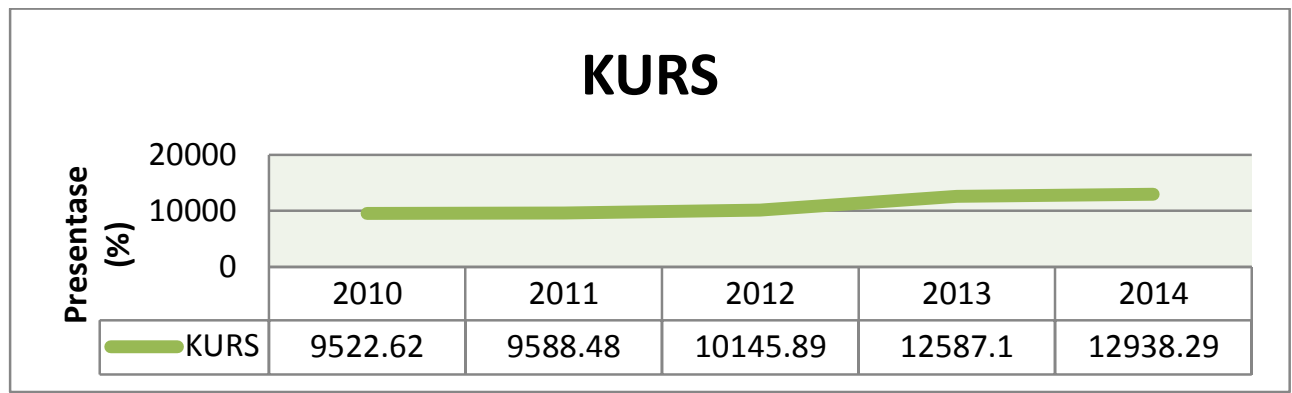

Sumber :Bank Indonesia, (2015).

Perubahan nilai tukar nominal akan diikuti oleh perubahan harga yang sama yang menjadikan perubahan tersebut tidak berpengaruh terhadap posisi persaingan relatif antara perusahaan domestik dengan pesaing luar negerinya dan tidak ada pengaruh terhadap aliran kas.

\section{Perkembangan Tingkat BI Rate}

Menurut PBI No. 4/10/PBI/2002 tentang Sertifikat Bank Indonesia, SBI adalah surat berharga dalam mata uang Rupiah yang diterbitkan oleh Bank Indonesia sebagai pengakuan utang berjangka waktu pendek. Tingkat suku bunga ini ditentukan oleh mekanisme pasar berdasarkan sistem lelang. Berikut ini grafik perkembangan tingkat BI Rate pada periode 20102014.

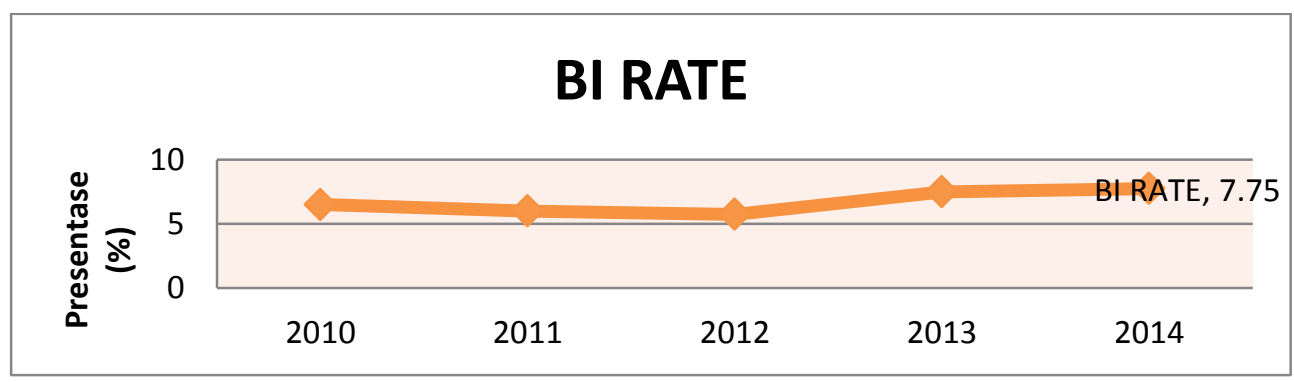

Sumber :Bank Indonesia, (2015).

Dalam grafik diatas terlihat suku bunga BI Rate mengalami pergerakan yang meningkat dari tahun 2012 kemudian mengalami kenaikan yang cukup tinggi pada akhir tahun 2013 dengan presentasi Dalam penelitian ini tingkat suku bunga BI Rate dijadikan sebagai variabel eksternal yang mempengaruhi harga saham sector property dan real estate. 


\section{Uji Hipotesis}

Dari hasil pengujian spesifikasi model, di dapatkan bahwa model yang paling tepat untuk digunakan adalah Random Effect Model (REM).proses selanjutnya adalah melakukan evaluasi dan interpretasi untuk mengetahui seberapa baik hasil regresi yang didapatkan. Karena metode yang terpilih dalam penelitian ini adalah metode random effect maka pengujian hipotesis dilakukan berdasarkan nilai dari hasil regresi pada metode random effect.

Uji kriteria statistik random effect mengakomodir perbedaan antar individu atau antar waktu melalui error.Teknik ini mengasumsikan bahwa semua komponen error tidak berkorelasi antar waktu dan juga tidak berkorelasi antar unit croos sectionnya dan tidak berautokorelasi.Uju Kriteria statistic random effect dilakukan dengan melakukan uji $\mathrm{t}$, uji $\mathrm{F}$ dan uji koefesien detreminasi $\left(R^{2}\right)$.

Berikut hasil estimasi random effect model yang peneliti lakukan:

\section{Tabel 4.8: Hasil Estimasi Model Random Effect}

Dependent Variable: SAHAM?

Method: Pooled EGLS (Cross-section random effects)

Date: 12/20/15 Time: 15:41

Sample: 20102014

Included observations: 5

Cross-sections included: 8

Total pool (balanced) observations: 40

Swamy and Arora estimator of component variances

\begin{tabular}{lcccc}
\hline \hline Variable & Coefficient & Std. Error & t-Statistic & Prob. \\
\hline \hline C & -397.8121 & 813.6946 & -0.488896 & 0.6280 \\
ROE? & -51.05111 & 17.72306 & -2.880491 & 0.0067 \\
EPS? & 8.138404 & 0.637517 & 12.76577 & 0.0000 \\
KURS? & 0.277446 & 0.167676 & 1.654655 & 0.1069 \\
BI_RATE? & -223.6381 & 290.0580 & -0.771012 & 0.4459 \\
Random & Effects & & & \\
(Cross) & & & & \\
_APLN--C & -321.1883 & & & \\
_BSDE--C & -29.83783 & & & \\
_ASRI--C & 113.1499 & & &
\end{tabular}

QE Journal | Vol.04 - No.04 December 2015 - 230 


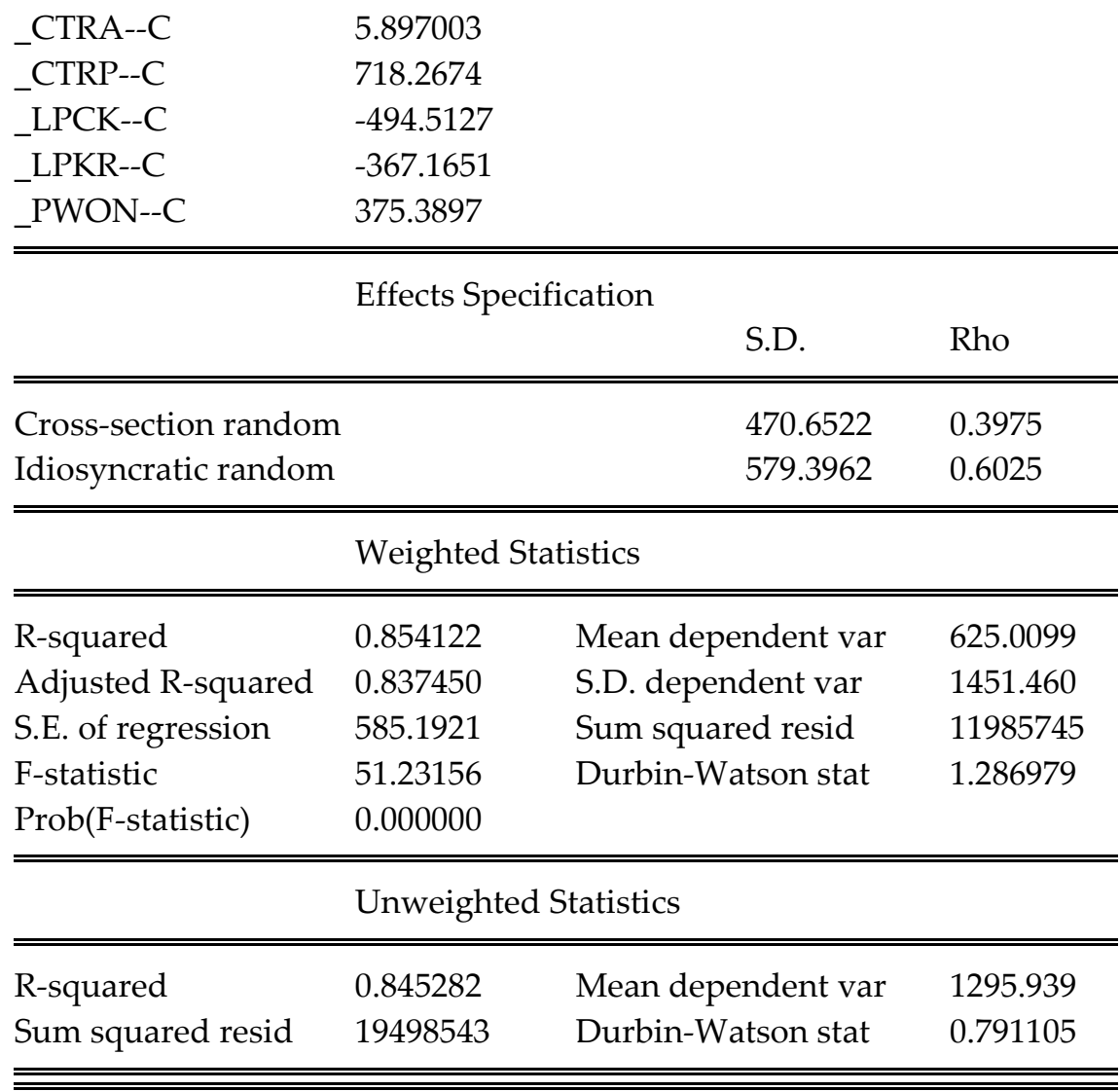

Sumber: Data Diolah Eviews 7

\section{Uji Koefisien Determinasi (Uji R²)}

Koefisien determinasi $\left(R^{2}\right)$ pada intinya menunjukkan presentase variasi nilai variabel dependen yang dapat dijelaskan oleh persamaan regresi yang dihasilkan. Dengan melihat kembali tabel 4.8, maka dapat dilihat bahwa nila $\mathrm{R}^{2}$ dari model penelitian yang diperoleh menggunakan random effect memiliki nilai sebesar 0.854122 . Hal ini artinyaa sebesar $85 \%$ variabel Return On Equity (ROE), Earning Per Share (EPS), Kurs dan BI Rate mempengaruhi harga saham sector property dan real estate, sedangkan sisanya $15 \%$ dipengaruhi oleh variable-variabel lainnya diluar variabel tersebut. Dengan demikian, variabel-variabel bebas yang digunakan dalam penelitian ini sudah dapat menjelaskan variabel terikatnya dengan baik. 


\section{Uji Signifikan Secara Parsial ( Uji t )}

Uji statistik $\mathrm{t}$ pada dasarnya menunjukkan seberapa jauh pengaruh suatu variabelindependensecaraparsialdalammenerangkanvariabeldependen. Uji $\mathrm{t}$ dilakukan dengan menggunakan uji satu sisi (one tail test), dengan $\alpha=$ $5 \%$, maka diperoleh $\mathrm{t}$-tabel sebagai berikut : $\mathrm{t}$-tabel $=\alpha ; \mathrm{df}=(\mathrm{n}-\mathrm{k})$

$$
\begin{aligned}
& =5 \% ; \mathrm{df}=40-5 \\
& =0,05 ;=35 \\
= & 2.03
\end{aligned}
$$

Berdasarkan (tabel 4.8)diperoleh beberapa kesimpulan sebagai berikut :

1. Return On Equity (ROE) memiliki nilai t-hitung sebesar -2.880491 dengan tingkat probabilitas sebesar 0.0067 yang berada dibawah $\alpha=5 \%$. Karena nilai signifikansi $<\alpha=5 \%$ dan nilai t-hitung sebesar $-2.880491>\mathrm{t}$-tabel sebesar 2.03 maka dinyatakan bahwa Return On Equity (ROE) berpengaruh negatif dan signifikan terhadap harga saham sector property dan real estate. Hasil penelitian ini sesuai dengan hipotesis yang dinyatakan sebelumnya bahwa Return On Equity (ROE) berpengaruh negative terhadap harga saham sector property dan real estate

2. Earning Per Share (EPS) memiliki nilai t-hitung sebesar 12.76577 dan tingkat probabilitas sebesar 0.0000 yang berada dibawah $\alpha=5 \%$. Karena nilai signifikansi $<\alpha=5 \%$ dan nilai t-hitung sebesar 12.76577> t-tabel sebesar 2.03 maka dinyatakan bahwa Earning Per Share (EPS) berpengaruh positif dan signifikan terhadap harga saham sector property dan real estate. Hasil penelitian ini sesuai dengan hipotesis yang dinyatakan sebelumnya bahwa Earning Per Share (EPS) berpengaruh positif signifikan terhadap harga saham sector property dan real estate.

3. Kurs memiliki nilai t-hitung sebesar 1.654655 dan tingkat probabilitas sebesar 0.1069 yang berada diatas $\alpha=5 \%$. Karena nilai signifikansi $>\alpha=$ $5 \%$ dan nilai t-hitung sebesar $1.654655<\mathrm{t}$-tabel sebesar 2.03 maka dinyatakan bahwa Kurs berpengaruh positif dan tidak signifikan terhadap harga saham sector property dan real estate. Hasil penelitian ini sesuai dengan hipotesis yang dinyatakan sebelumnya bahwa Kurs 
berpengaruh positif terhadap harga saham sector property dan real estate.

4. BI Rate memiliki nilai t-hitung sebesar -0.771012 dan tingkat probabilitas sebesar 0.4459 yang berada diatas $\alpha=5 \%$. Karena nilai signifikansi $>\alpha=$ $5 \%$ dan nilai t-hitung sebesar $-0.771012<\mathrm{t}$-tabel sebesar 2.03 maka dinyatakan BI Rate berpengaruh negatif dan tidak signifikan terhadap harga saham sector property dan real estate. Hasil penelitian ini sesuai dengan hipotesis yang dinyatakan sebelumnya bahwa BI Rateberpengaruh negative terhadap harga saham sector property dan real estate.

\section{Uji Signifikan Secara Simultan (Uji Statistik F)}

Uji statistik F digunakan untuk mengetahui pengaruh antara variabel independen secara simultan terhadap variabel dependen (Ghozali, 2006).Apabila tingkat signifikansi variabel independen terhadap variabel dependen secara keseluruhan berada dibawah $\alpha=5 \%$, maka dapat dikatakan bahwa variabel-variabel tersebut berpengaruh secara signifikan. Berdasarkan (tabel 4.8), dapat dilihat bahwa nilai probabilitas F-statisticnya sebesar 0,000000 dimana nilai tersebut lebih kecil dari $\alpha=5 \%$. Dan nilai Fstatistik dari model penelitian ini sebesar 51.23156. Nilai ini lebih besar dibandingkan F-tabel yaitu sebesar 2,64. Hal ini berarti variabel Return On Equity (ROE), Earning Per Share (EPS), Kurs dan BI Rate secara simultan memiliki pengaruh yang signifikan terhadap harga saham sector property dan real estate.

\section{Hasil Intrepetasi}

Adapun hasil regresi data panel dengan menggunakan model Random Effect, maka dapat dilihat hasil sebagai berikut :

Tabel 4.9: Ringkasan Hubungan dan Signifikansi Hasil Regresi Data Panel

\begin{tabular}{|c|c|c|c|c|}
\hline & & $\begin{array}{l}\text { Hypothesis } \\
\text { Sign }\end{array}$ & $\begin{array}{l}\text { Output } \\
\text { Sign }\end{array}$ & Keterangan \\
\hline Variabel Terikat & Harga Saham & & & \\
\hline \multirow[t]{2}{*}{ Variabel Bebas } & ROE & Negatif & Negatif & Signifikan \\
\hline & EPS & Positif & Positif & Signifikan \\
\hline
\end{tabular}




$\begin{array}{llll}\text { KURS } & \text { Positif } & \text { Positif } & \text { Tidak Signifikan } \\ \text { BI Rate } & \text { Negatif } & \text { Negatif } & \text { Tidak Signifikan }\end{array}$

Sumber : Data diolah dengan Eviews 7.

Berdasarkan tabel 4.9 dapat dilihat bahwa terdapat kesesuaian antara hipotesis dan hasil dari analisis data menggunakan regresi data panel dengan menggunakan model random effect.

\section{SIMPULAN DAN SARAN}

\section{SIMPULAN}

Penelitian ini mencoba untuk menjawab tujuan penelitian, yaitu untuk menganalisis pengaruh Return On Equity (ROE), Earning Per Share (EPS), Kurs dan BI Rate terhadap harga saham sektor property dan real estate yang terdaftar di Bursa Efek Indonesia Hasil pengujian hipotesis dengan menggunakan model regresi data panel dengan lima empat variabel independen (Return On Equity (ROE), Earning Per Share (EPS), Kurs dan BI Rate ) dan satu variabel dependen yaitu harga saham menunjukkan hasil sebagai berikut :

1. Berdasar hasil pengujian hipotesis 1 menunjukkan bahwa variabel Return On Equity (ROE) berpengaruh negatif dan signifikan terhadap harga saham sector property dan real estate.

2. Hasil pengujian hipotesis 2 menunjukkan bahwa variabel Earning Per Share (EPS) berpengaruh positif dan signifikan terhadap harga saham sector property dan real estate

3. Hasil pengujian hipotesis 3 menunjukkan bahwa variabel Kurs berpengaruh positif dan tidak signifikan terhadap harga saham sector property dan real estate.

4. Hasil pengujian hipotesis 4 menunjukkan bahwa variabel BI Rate berpengaruh negatif dan tidak signifikan terhadap harga saham sector property dan real estate. 


\section{SARAN}

Berdasarkan simpulan di atas, penelitian ini memiliki beberapa saran yang dapat diajukan yaitu bagi para investor maupun calon investor dalam berinvestasi sebaiknya harus memperhatikan informasi-informasi yang terdapat dalam laporan keuangan, khususnya neraca dan laporan laba rugi sebagai acuan dan bahan pertimbangan dalam mengambil keputusan investasi yang tepat dan menguntungkan. Bagi perusahaan agar lebih meningkatkan profitabilitas dan mengelola total aktivanya dengan efektif agar dapat lebih menarik minat para investor untuk berinvestasi.

\section{DAFTAR PUSTAKA}

Ali, Mashud. 2004. Asset Liability Management: Menyiasati Resiko Pasar dan Resiko Operasional. Jakarta : PT. Gramedia

Bank Indonesia. 2002. Peraturan Bank Indonesia No, 4/10/PBI/2002. Jakarta: Bank Indonesia

Bank Indonesia. 2004. Surat Edaran Bank Indonesia No, 6/23/DPNP tanggal 31 Mei 2004. Jakarta: Bank Indonesia

Bank Indonesia. 2013. Peraturan Bank Indonesia No, 15/15/PBI/2013. Jakarta: Bank Indonesia

Darmawan, Komang. 2004. Analisis Rasio-Rasio Bank. Info Bank. www.bi.go.id. Diakses pada 29Desember 2015.

Dendawijaya, Lukman. 2005. Manajemen Perbankan. Jakarta : Penerbit Ghalia

Indonesia

Ghozali, Imam. 2009. Ekonometrika, Teori dan Aplikasi dengan Program SPSS. Semarang : Badan Penerbit Universitas Diponegoro

Gujarati, Damondar. 1999. Ekonometrika Dasar, Terjemahan oleh Sumarno Zain. Jakarta: Erlangga

Sugiyono. 2010. Metode Penelitian Bisnis. Bandung: Alfabeta

Susilo, Y.Sigit Triandaru, dan A. Tatok Budi Santoso. 2006. Bank dan Lembaga Keuangan lain. Jakarta: Salemba Empat

Widarjono, Agus. 2007. Ekonometrika Teori dan Aplikasi untuk Ekonomi dan Bisnis. Edisi Kedua. Yogyakarta: Fakultas Ekonomi UII. 